\title{
Tekmeria
}

Vol 10 (2011)

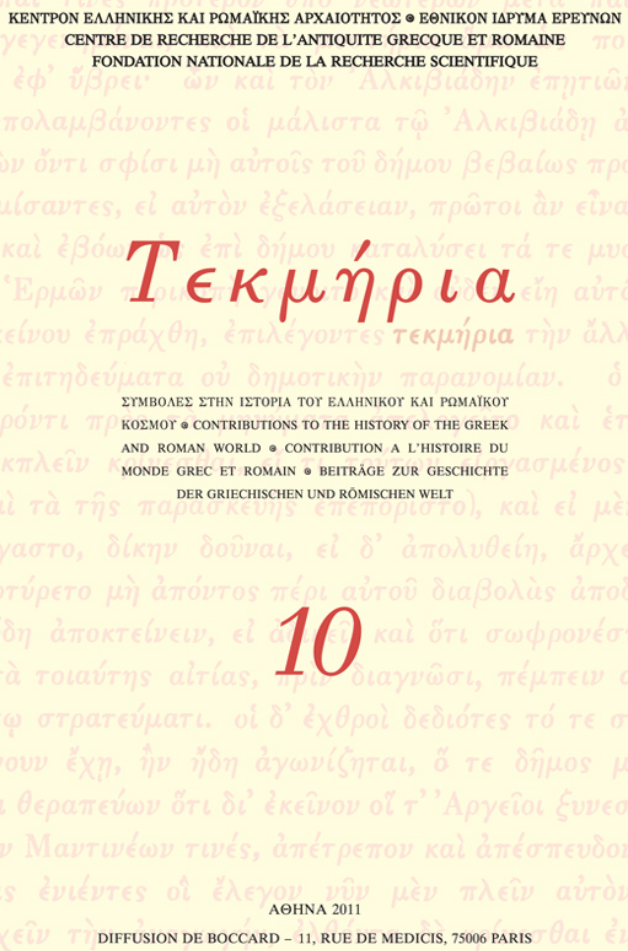
A list of sales from Mieza and the constitution of extensive landed properties in the Central Macedonian plain

\section{B. HATZOPOULOS}

doi: $10.12681 /$ tekmeria.268

DIFFUSION DE BOCCARD - 11, RUE DE MEDICIS, 75006 PARIS

\section{To cite this article:}

HATZOPOULOS, M. B. (2011). A list of sales from Mieza and the constitution of extensive landed properties in the Central Macedonian plain. Tekmeria, 10, 47-69. https://doi.org/10.12681/tekmeria.268 


\section{A list of sales from Mieza and the constitution of extensive landed properties in the Central Macedonian plain}

Several years ago the study of the territory and the villages of Beroia made me realise that in Roman times extensive landed property was well attested in the Central Macedonian Plain. ${ }^{1}$ The inscriptions from the sanctuary of Leukopetra in the territory of Beroia mention two estates $(\chi \omega \rho i \alpha)$, one of which provided with the typical protective tower of rural properties $(\beta \alpha \dot{\alpha} \rho){ }^{2}$ while another inscription from the urban centre itself recorded the construction by a family of rich landowners of an aqueduct for the adduction of water from their estates to the city centre. The subsequent discovery and publication of a boundary stone delimitating - at least according to my interpretation- the territory of the city of Kyrrhos from that of a rich lady Ioulia Men(n)eis, ${ }^{3}$ also known from a dedication from the adjoining city of Skydra and related to the prominent family of Beroia which offered the aqueduct to that city, ${ }^{4}$ showed that in Roman times there existed a group of very prosperous landowners who had acquired wealth and status equal to that of small cities such as Kyrrhos or Skydra. Even the once important city of Mieza situated between Beroia and Skydra seems to have lost its civic status and to have been reduced to an agricultural territory annexed by its bigger southern neighbour, since in an inscrip-

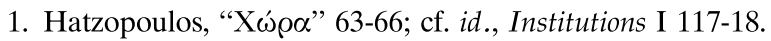

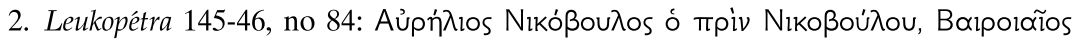

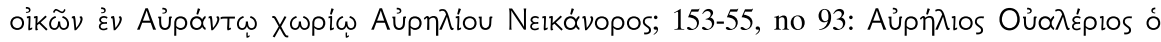

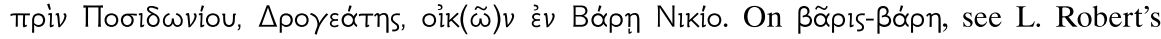
review of A. Rehm, Didyma II. Die Inschriften (Berlin 1958) in Gnomon 1959, 670 (OMS III 669-70) with references.

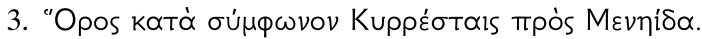

4. For the changing readings and for the interpretation of the inscription by the first editor, see BullEpigr 1988, 837; 1990, 461; 1994, 405; 2002, 265. It seems that now the editor primus has reverted to his first reading. For the family connections of Ioulia Men(n)eis, see Tataki, Beroia 191-92, no 692; 199, no 724-725; 200, no 726. 


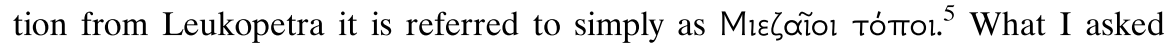
myself was whether such large estates should be considered a late development connected with the Roman conquest or as a traditional feature of rural Macedonia. ${ }^{6}$

For the late classical and Hellenistic period we knew of the existence of royal grants of extensive estates, doreai, in Macedonia both from literary ${ }^{7}$ and epigraphic sources. ${ }^{8}$ As it was natural, all attested doreai (with the exception of the alleged but dubious grants to the Athenian politicians Kallimedon and Hegemon in Beroia and Pella respectively) concerned the newly conquered lands of Greater Macedonia by Philip II, especially Chalkidike, where confiscated property of the defeated enemy had be converted into royal land.

The grant of Cassander to Perdikkas son of Koinos gave us a first glimpse of the importance of these landed properties by the enumeration of at least three estates in the territories of the former cities of Sinos, Olynthos and Spartolos. ${ }^{9}$ It was, however, the publication of Lysimachos' grant to Limnaios son of Harpalos which for the first time provided us with precise figures of the size of the donated estates. This otherwise unknown royal protégé received three estates situated respectively in the territories of the former cities Sermylia, Olynthos and Strepsa and totalling 2480 plethra (or 217.25 hectares, if we calculate on the basis of $876 \mathrm{~m}^{2}$ per plethron $).{ }^{10}$ Another aspect of extensive landed properties was revealed to us by the publication of a letter of Antigonos Gonatas, which has survived in two copies, one from Dion and the other from Apollonia in Mygdonia. ${ }^{11}$ It mentioned an estate named "Mysia", situated between Asikos and Lake Pyrrolia in central Mygdonia, which a certain Noumenios had given to his sons to exploit. Once again the estate was probably situated in the territory of a former city, that of Pyrrolos, which seems to have been annexed by Apollonia.

An old and - at the same time- new inscription from Mieza offers us now for

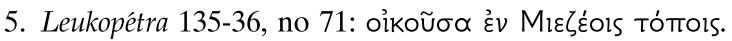

6. Hatzopoulos, "X $\omega \rho \alpha$ " 66. On the scarcity of information about land ownership in Roman Macedonia until very recently; cf. Fanoula Papazoglou, "Macedonia under the Romans", in Macedonia 4000 Years of Greek History and Civilization (Athens 1983) 200-201.

7. Diod. 16.53.3; cf. Theopompus, FGrHist 115, 224. See also [Aisch.], Epist. 12.8.

8. Hatzopoulos, Donation 22-23.

9. For a recent discussion of this grant, see BullEpigr 2008, 340.

10. For both grants, see Hatzopoulos, Donation 22-26; 17-18; 36-43 and 49-54.

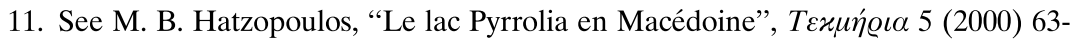
70 and, $i d$. ., "Le nom antique du lac Koroneia (ou d'Hagios Basileios ou de Langadas) en Macédoine", CRAI 2005, 203-214. 
the first time an insight into the development of extensive landed properties in the Old Kingdom, the heartland of Macedonia. A first fragmentary text of a list of sales was discovered in 1955 in the filling of the antechamber of the "Tomb of the Judgement" at Leukadia and was published by Ph. Petsas in $1961 .^{12}$ A second one was unearthed in 1998 during restoration works necessitating the removal of the remaining filling in the antechamber of the same tomb, and was published with commendable celerity and thoroughness by Maria Lilimbaki-Akamati and Liana Staphani under the title "' $\Omega \nu \alpha i$ ह่ $\chi \tau \tilde{\eta} \varsigma$ 'H $\mu \alpha \theta i \alpha \varsigma$ II", ${ }^{13}$ which was in itself an homage to the memory of this pioneer of Macedonian archaeology.

The two fragments practically join with one another and restitute to us a rectangular plaque $0.504 \times 0.545 \times 0.112$ (fig. no 1 ). However, this piece is the result of remodelling for a different use of the original plaque that carried the inscription laid out on two "pages". In the reuse of the plaque a thin slice with one line of text was removed, its right part with most of the second "page" was also removed and dowels were bored on its right and left sides, which were destined to become respectively the upper and lower part of the stone in its new use. ${ }^{14}$ It was then that the deep perpendicular furrow was traced in an apparent first and incomplete attempt to remove the right part of the original plaque. We can thus conclude that the plaque as we see it now is almost complete on three sides: top, bottom and left, and, consequently, that the four practically complete deeds of sale on the left "page" and the six incomplete ones on the right one represent the full contents of the document, which were consecutively inscribed in that order.

The editors of the second fragment produced a competent and exhaustive study. Their publication comprises the conditions under which the discovery of the second fragment was made, a detailed description of the stone, a presentation of the formulae of the documents, an edition of the four sales of the left 'page', and a new edition of the six fragmentary inscriptions of the right 'page' in the light of the almost complete texts of the four sales of the left one.

All ten deeds of sale concern acquisitions of an equal number of properties by Zopyros son of Gorgias. The first four of the left "page" (fig. no 2) were enacted in the Macedonian month of Peritios (January) of the year when epistates was Onomarchos, priest of Asklepios Nikanor and Eupolemos and Nikanor held the

12. Petsas, "' $\Omega v \alpha i$ ' 1-57 (SEG 24 [1969] 524; Giouni, "' $2 v \alpha i$ ' 29-30); Hatzopoulos, Institutions II 106-108, no 92); cf. BullEpigr 1965, 231.

13. Lilimbaki - Stephani, "' $\Omega \nu \alpha \imath$ ' 155-96.

14. Contrary to the editors of the second fragment, I use the terms "right" and "left" from the point of view of the onlooker. 
M. B. HATZOPOULOS

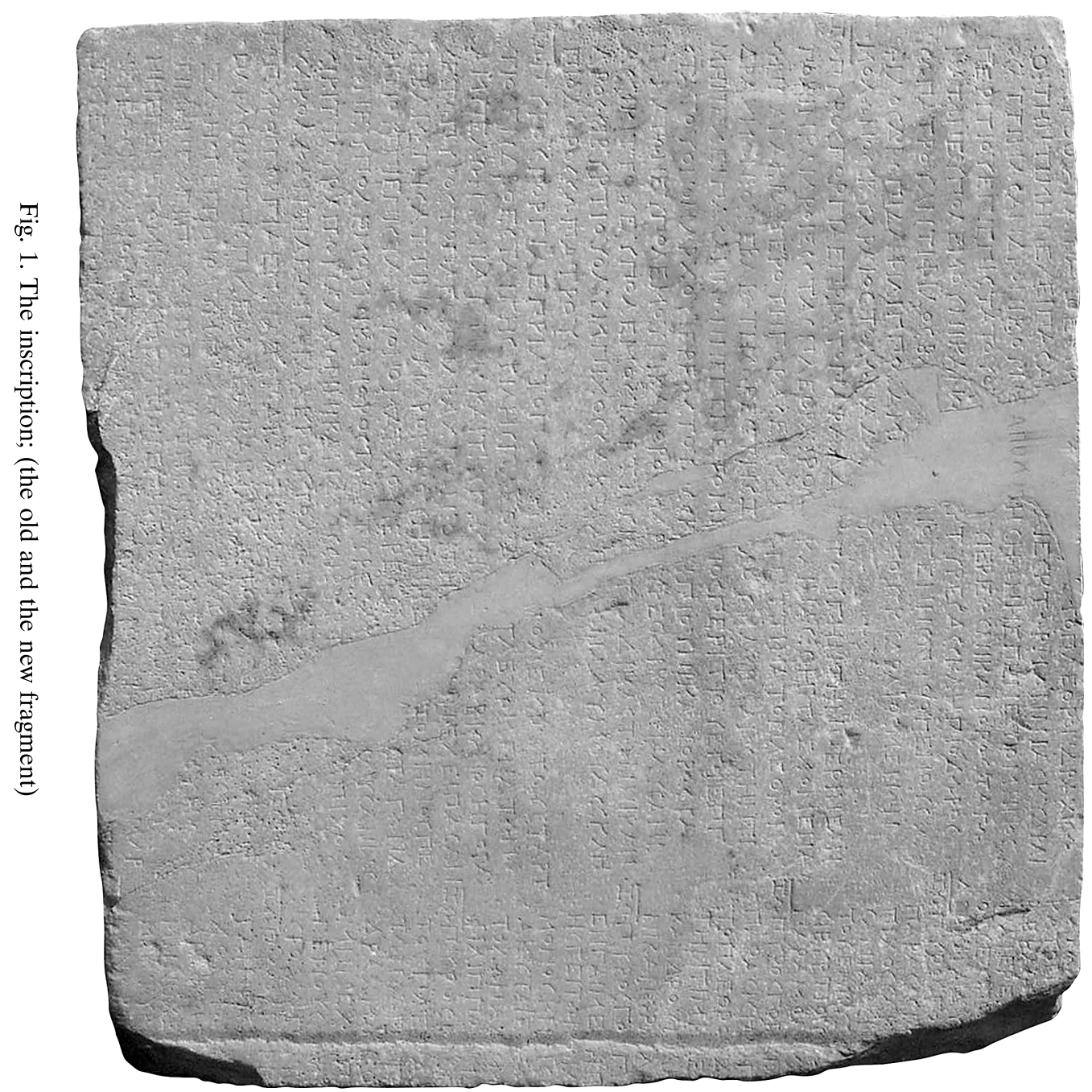




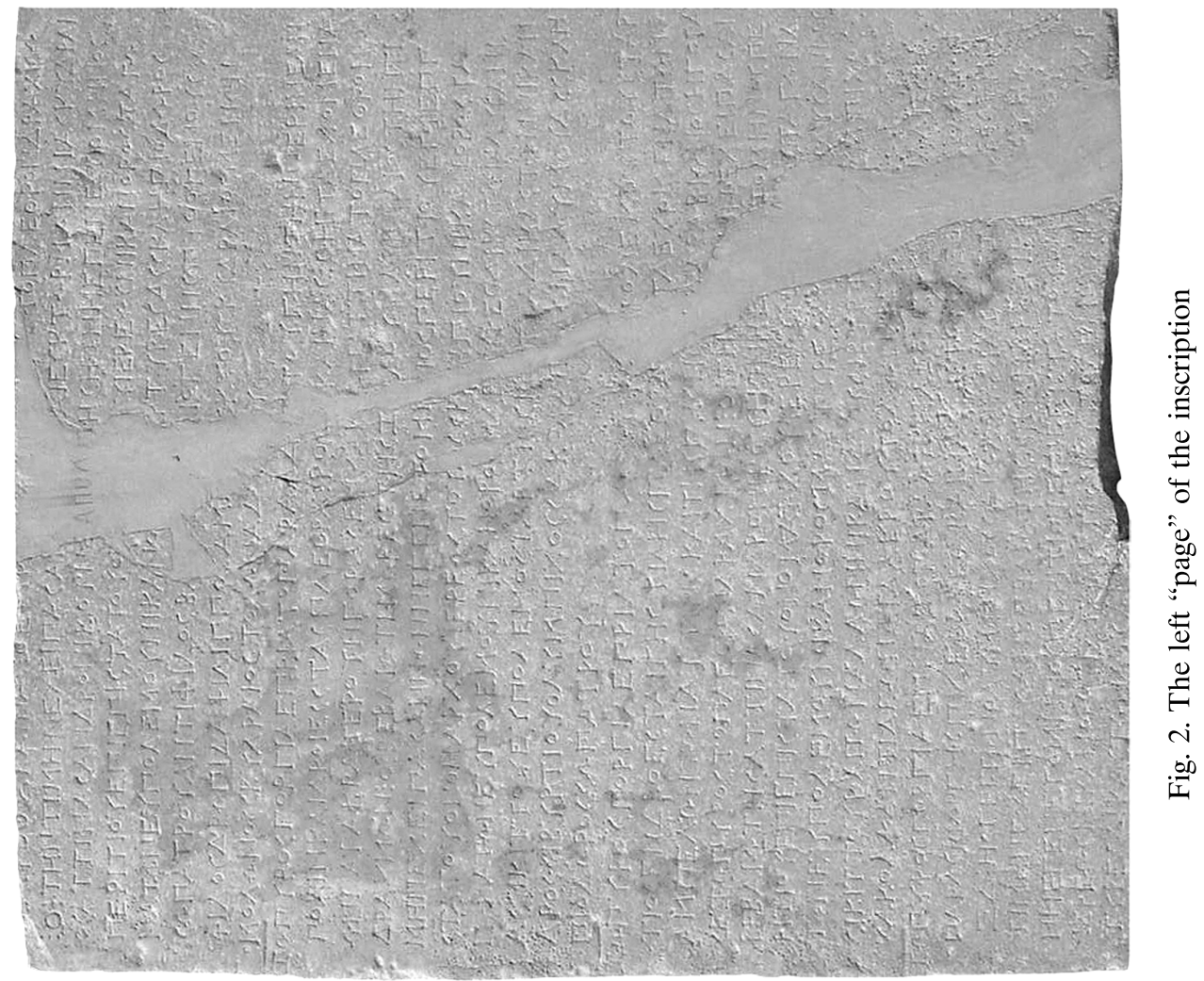


office of TAGOIATOI, which is discussed below. Each of these four deeds includes the following elements, besides the date: the name of the purchaser, the name of the vendor, the nature or/and the location of the property, its extent expressed in plethra and akainai, its unit price, the names of the witnesses and of the guarantors, and, finally, the payment of the transaction and the amount paid.

The first deed concerned a piece of land of 179 plethra and 75 akainai (15.746 hectares) near a place called Droiestai at the price of 70 drachmae per plethron. Guarantors to the sale were one citizen of Skydra and one citizen of Neapolis and it was witnessed by seven persons, two of which were citizens of Skydra.

The object of the second deed was another piece of land of 179 plethra and 78 akainai (15.749 hectares) situated near Neapolis and Droiestai and adjoining the property that Zopyros had already bought from a certain Krateros and the property of the citizen of Neapolis who served as guarantor in the previous deed, at the price of 70 drachmae per plethron. There was only one guarantor, a citizen of Marinia,

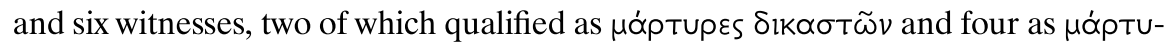

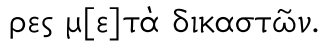

The third act concerned a field at Droestai adjoining the vineyards of the same citizen of Neapolis as in the previous deed and a piece of land previously bought by Zopyros from a certain Bion. The number of plethra has been lost but the unitary price is still 70 drachmae. There are no guarantors, but only one witness

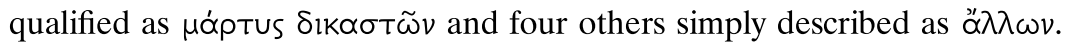

In the fourth deed Zopyros buys five plethra and fifty akainai (4.818 hectares) of land adjoining the property of Zopyros himself and of another citizen of Mieza near the (river?) Sisias at the price of 64 drachmae per plethron. There are no

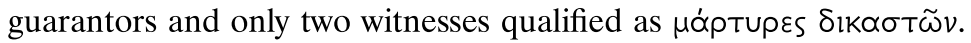

The next six deeds which were inscribed on the right page (fig. no 3 ) were much shorter and presented a simplified dating formulary excluding the mention of the month, of the deity ministered by the priest and of the ТАГОІАТОI.

The fifth, sixth, seventh and eighth deed were enacted in the Macedonian year when Eakytas was epistates and Nikandros was priest (of Asklepios) at Mieza. The first three of these concerned properties bought by Zopyros near the (river?) Sisias and the fourth at a place called Gaimeion. No indication of size or price survives.

The last two deeds were enacted in the Macedonian year when [Dio]genes (rather than [Pytho]genes) was priest (of Asklepios) at Mieza. The name of the epistates does not survive. The size of the properties acquired by Zopyros is missing. We only know that the last deed concerned once more land at Gaimeion and that the unitary price of the property bought by the ninth deed was 70 drachmae. 


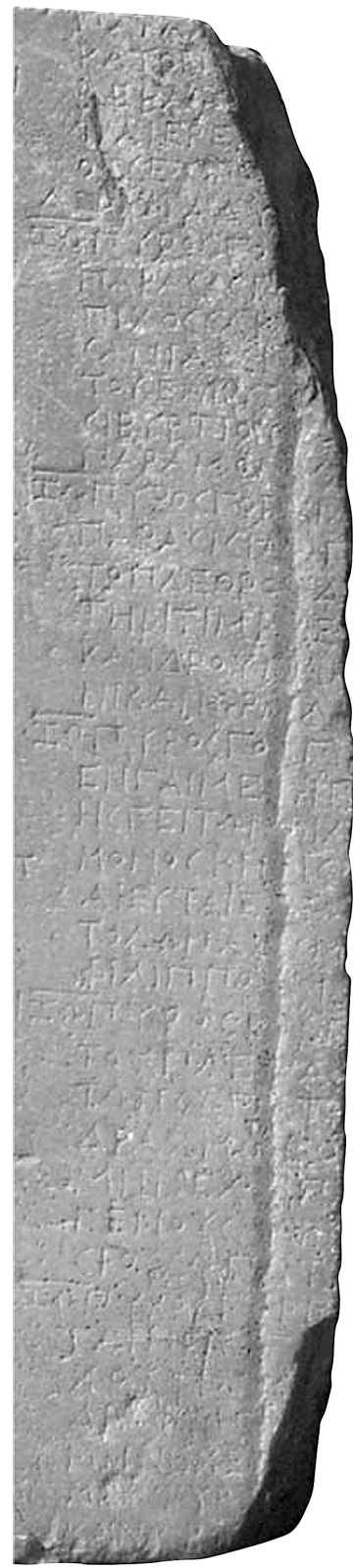

Fig. 3. The right "page" of the inscription 
It is only natural that texts so rich in information of all sorts would deserve an equivalent commentary. I have already formulated some remarks and suggested a number of corrections, ${ }^{15}$ and I discuss the significance of this inscription for our knowledge of Macedonian onomastics in a separate paper. ${ }^{16}$ In the present paper I shall limit myself to the two following issues: 1) the political institutions of Mieza as a Macedonian city; 2) some questions of historical topography and the conclusions about the economic and social conditions in Hellenistic Mieza which can be drawn from them.

\section{1) Political institutions}

The four texts of the left 'page' probably represent the complete and exact copies of the deeds that were deposed in the public archives of Mieza, as opposed to the six texts of the right 'page' which are only abridged versions of the corresponding documents. ${ }^{17}$ Thus, while all ten deeds include the names of the purchaser and the vendor, the nature or/and the location of the property sold, the unit price, the fact of the payment, the date and the names of the witnesses and of the guarantors, the six last documents omit the total sum paid for the transaction, abridge the date to the mention of the epistates and of the priest (without naming the deity ministered by him), leave aside the couple of TAGOIATOI, and, finally, do not distinguish

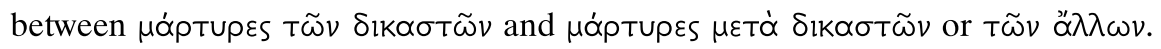

The nearly complete restoration of the four first deeds of the inscription and the improved reading of the last six, thanks to the discovery of the new fragment, raise four questions concerning the political institutions of Macedonia.

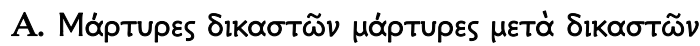

Judges are epigraphically attested in Macedonia both as civic magistates in a royal diagramma and a decree from Thessalonike ${ }^{18}$ and as royal officers entrusted with the settling of civil litigations in a deed of sale from Tyrissa(?). ${ }^{19}$ Judges as witnesses are mentioned in deeds of sale and of tenancy at Mylasa and Olymos in Caria

15. BullEpigr 2006, 252.

16. M. B. Hatzopoulos, "Echantillons onomastiques de l'arrière-pays macédonien au IIIe siècle av. J.-C.” in R. W. V. Catling छ F. Marchand (eds), Onomatologos. Studies in Greek Personal Names Presented to Elaine Matthews (Oxford 2010) 356-365.

17. Cf. Faraguna, "Archivi" 104 and n. 143 with the relevant bibliography.

18. Hatzopoulos, Institutions II 39-40, no 15 , and 67-68, no 50.

19. Chrysostomou, " $\Delta \iota x \alpha \sigma \tau \alpha \imath " 22-45$. 
( $\mu \alpha \rho \tau \nu \rho \varepsilon \varsigma \delta \iota x \alpha \sigma \tau \alpha i),{ }^{20}$ and in deeds of donation and division of property among

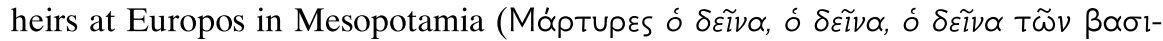

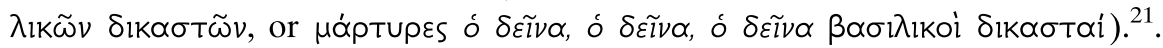
There is no doubt that, as in the former example from Europos, the genitive case

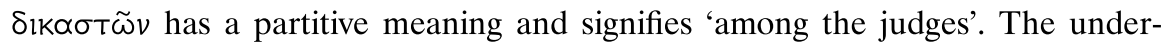
standing of the antithetic qualification of witnesses at Mieza as $\tau \tilde{\omega} \nu{ }^{\prime} \alpha \lambda \omega \nu$ or $\mu \varepsilon \tau \dot{\alpha}$ $\delta ı \kappa \alpha \sigma \tau \tilde{\omega} \nu$ is enhanced by the parallel formulation of an emancipation deed from Bouthrotos in Epirus, which makes the similar distinction between witnesses $\tau \tilde{\omega} \nu$

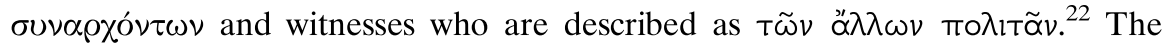
unabridged deeds allow us to identify the two judges who assume the office of witnesses when Onomarchos was epistates and Nikanor priest of Asklepios. These are Lysanias son of Sikittas(?) and Eupolemos son of Startis, who appear in the second and the fourth deed, while in the third one only Lysanias son of Sikittas(?) is mentioned. Judging from the absence of witnesses of this category in the first deed, it would seem that their presence was not indispensable in each and every deed.

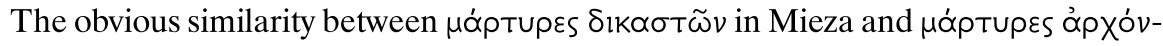
$\tau \omega \nu$ in Bouthrotos indicates that the former too belonged to the general category of " $\rho \chi \supset \nu \tau \varepsilon \varsigma$, that is to say of civic magistrates. This conclusion is not without significance for the interpretation of the term ТАГ $\Omega N A T \Omega N$.

\section{B. TAГ $\Omega N A T \Omega N$}

This term, followed by two names, appears as an element of the date in the first four deeds, which seem to be exact copies of the original documents. In the editio princeps they are interpreted as the genitive plural of an unattested substantive * $\tau \alpha \gamma \omega v \alpha$ '́as, that would represent the title of a magistrate, a corrupted form of which would lie behind Hesychius' glossa ta yóvaya. ${ }^{23}$

Firstly it should be noted that the sequence of characters TAГ $\Omega N A T \Omega N$ does not appear here for the first time. It can also be read in the deed of sale from

20. W. Blümel, Die Inschriften von Mylasa, vol. II (Bonn 1987-1988) no 202; 224; 226; 806; 807; 810; 811; 816A; 824; 830; 833; 849; 904.

21. C. B. Welles et al., The Excavation at Dura-Europos. Final Report V (New Haven 1959), Part I, 98-109, no 18 and 19.

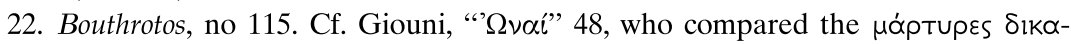

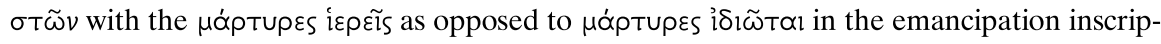
tions of Delphi. Cf. SEG 12 (1955) 235; 237; 242; 244; 252 etc.

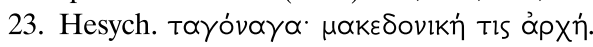


Asvestario (Tyrissa?). ${ }^{24}$ Its first editor read 'E $\pi i$ т $\alpha \gamma \tilde{\omega} \nu$ in its 19th line. In fact, on the stone, but also from the photograph, one can decipher the letters ЕПІТАГ $\Omega$ NAT $\Omega[$.$] . Secondly a composite word * \tau \alpha \gamma \omega \nu \alpha \dot{\tau} \alpha$ s can find no convincing etymol-

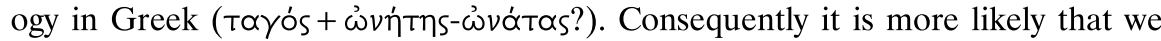
are dealing with two seperate words: $\tau \alpha \gamma \tilde{\omega} v \stackrel{\alpha}{\tau} \tilde{\omega} v$, the second of which is the genitive plural of the anaphoric pronoun aủtós, with the reduced form of the diphthong, which is attested in Athens from the fourth century B.C., but which seems to have appeared earlier in the Macedonian dialect and to have remained in use in the dating formula. In this paricular usage the pronoun would have the emphatic meaning of 'proper', 'par excellence'. Thus, if in Macedonia tayós had the general meaning of 'magistrate', $\tau \alpha \gamma \tilde{\omega} \nu$ ' $\tau \tilde{\omega} \nu$ would mean "when magistrates proper were". It is this formula that lies perhaps behind the corrupt glossa of

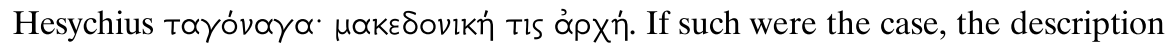
of Eupolemos and Nikanor as 'magistrates proper' may be destined to counterdistinguish them from the other two magistrates Lysanias son of Sikittas(?) and Eupolemos son of Startis, who are simply listed as 'judges'. But there might be another interpretation of this formula. In a recent seminar K. Buraselis evoked the possibility that the anaphoric pronoun referred to the aforementioned epistates Onomarchos and priest of Asklepios Nikanor, who along with Eupolemos and the other Nikanor constituted perhaps the college of the tagoi. ${ }^{25}$ This suggestion provides a most satisfactory solution in the case of the sales from Mieza, but encounters a major difficulty concerning the sale of Asvestario, where neither an epistates nor a priest of Asklepios is mentioned, unless, of course, we suppose that they had figured in the beginning of the text on the upper part of the stone, which may have been broken off.

\section{Epistatai and priests}

The new fragment, with its almost complete text of four deeds of sale, offers us now the possibility to improve the restoration of the remaining six and to better follow the chronological order of the transactions. Zopyros son of Gorgias proceeded to four acquisitions of property in the month of Peritios (January) of the year when epistates was Onomarchos and priest of Asklepios Nikanor. There followed four others in the year when epistates was Eakytas and priest (of Asklepios) Nikandros.

24. Chrysostomou, " $\Delta \iota \varkappa \alpha \sigma \tau \alpha i ” " ~ 23-45$; cf. BullEpigr 1999, 349.

25. I wish to thank my friend Kostas Buraselis for his kind permission to mention this suggestion. 
Another transaction was carried out when [Dio?]genes was priest of (Asklepios) and a person whose name does not survive epistates. From the last deed of sale neither the name of the epistates nor that of the priest survives.

The concentration of ten transactions within the space of three geographically close locations (Droestai, Sisias, Gaimeion) and the involvement in them of a restricted cercle of individuals, who appear in a variety of capacities, as we shall see below, makes it very likely that the ten deeds date from three consecutive years. Be that as it may, what is significant and deserves being stressed is that not only the eponymous priest of Asklepios, but also the epistates is replaced every year. ${ }^{26}$ This fact leaves little doubt that the epistates was a magistrate normally remaining in office no more than one year, which, in turn, strongly suggests that he was -formally at least- a civic magistrate and not a royal officer, as it has often been claimed. ${ }^{27}$

\section{A public or a private document?}

The two fragments of the plaque, as mentioned before, were discovered in the antechamber of the 'Tomb of the Judgement'. There is no doubt that the plaque recording the purchase of properties by Zopyros son of Gorgias was not originally intended to be part of that construction. One must keep in mind firstly that the lettering of the inscription suggests a date well into the third century B.C., ${ }^{28}$ whereas the tomb itself belongs to the last quarter of the fourth century, ${ }^{29}$ and secondly that it had already been reused when it ended up inside the antechamber of the tomb.

The Tomb of the Judgment was situated in open country at some two kilometres to the north-east of the city centre, probably on the road that joined Mieza to Pella skirting the northern shore of lake Loudiake. This interurban road, the surroundings of which were extensively used as a cemetery, ${ }^{30}$ probably went along country estates. The circumstances under which the reused plaque ended up in the tomb have not been elucidated. Ph. Petsas excluded the hypothesis that it had been

26. Cf. the priest and the prostates in the dating formula of the emancipation inscrip-

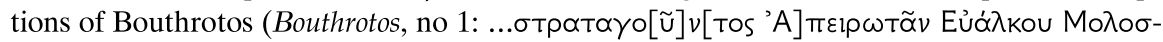

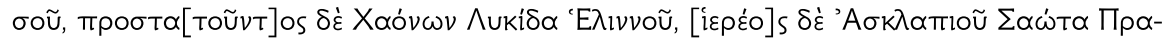

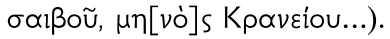

27. Cf. recently Hatzopoulos, "Quaestiones" 37-60.

28. Second half of the third century according to Petsas, "' $\Omega v \propto$ i" 39; last quarter of the third century according Lilimbaki - Stephani, "' $\Omega v \propto$ i" 161.

29. Katerina Rhomiopoulou, Lefkadia Ancient Mieza (Athens 1997) 29.

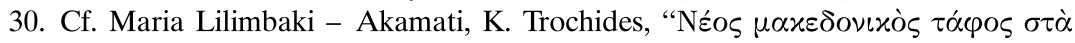
$\Lambda \varepsilon \cup \varkappa \alpha ́ \delta\llcorner\alpha$ 'H $\mu \alpha \theta i \alpha \varsigma$ ', $A E M \Theta 18,2004$ (Thessalonike 206) 465-66. 
placed on the tumulus and fell into the antechamber when the vault collapsed, but Maria Lilimbaki-Akamati and Liana Stephani admit the possibility that its presence there might be connected with the looting of the tomb or with the collapse of its roof, which caused part of the filling of the tumulus to subside into the tomb. Be that as it may, the question of the origin of the plaque remains unanswered. One can reasonably argue that it is a priori improbable that such a heavy object was carried the whole way, some two kilometres from the city centre, just to be dumped on the tumulus. Whatever the reason it was placed there, it is more likely that it had been found in the vicinity of the tomb, where it had been reused in some unidentifiable construction. It is true that it has been suggested that it had been originally erected at the office of the epistates or at a sanctuary, ${ }^{31}$ but this theory could enjoy some credibility only as long as the distance between tomb and the city centre was not known. The sole remaining argument in its favour, to wit that the register was a public document, is in fact far from certain.

Registers of deeds of sale are directly or indirectly known from various other parts of the Greek world, and from Macedonia itself. ${ }^{32}$ The two other Macedonian examples, however, are not very helpful, because of their mutilated condition. ${ }^{33}$ It is nevertheless clear that the one from Philippoi differs fundamentally from our document. It is a record of sales of sacred temene to unspecified buyers, drawn up by an official body that is not interested in the legal specifics of the transactions (identity of the purchasers and of the witnesses date of the deed, precise location of the property etc), but merely in the fact of the sale of sacred land itself and in the monies accruing thereof. ${ }^{34}$

The scope of the very fragmentary document from Drabeskos is uncertain. It preserves four more or less complete entries consisting of a) a name in the nomi-

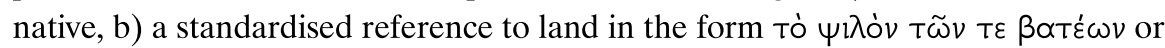

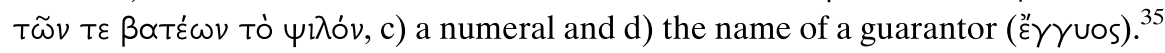

31. Petsas, "' $\Omega \nu \alpha i$ " 30; Giouni, "' $\Omega \nu \alpha i$ " 28.

32. Faraguna, "Archivi" 65-115.

33. Chrysostomou, " $\Delta \iota x \alpha \sigma \tau \alpha i$ " $26-27$, considers that the inscribed block that he publishes is part of the register of the transactions enacted in the community (Tyrissa) which was kept at a local sanctuary. However, as he recognises himself in the course of his study (p. 2930 ), the inscribed block does not contain a list of transactions but a single deed, along with its antecedents, establishing the ownership of some vineyards by a certain Polyainos.

34. Hatzopoulos, Institutions II 98-99, no 83.

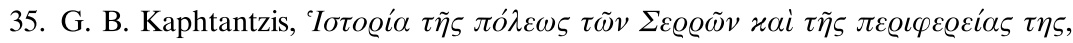
vol. I (Athens 1967) 342-43, no 568; cf. Giouni, ' $2 \nu \alpha i$ 30-31. 
We do not know whether the name in the nominative belongs to a buyer or to a seller. We do not very well understand the standardised formula referring to the land. We cannot decipher the numerals. We can only wonder why all the names with one possible exception are "barbaric". If we presume that, as in the other known deeds of sale, the name in the nominative is that of the purchaser, the absence of the name of the vendor points to an official document recording the sale of public (or at least not private) land. This is in conformity with the Athenian examples of sales of public property by the poletai. ${ }^{36}$

The case of the Tenos register is again different, for it records in chronological order transactions between private persons enacted in the presence of civic magistrates (đ̊otuvónol). ${ }^{37}$

The list of sales from the Tomb of the Judgment does not conform to any of these examples, for it is not a register of sales of sacred or civic land drawn up by a public authority like the documents from Philippoi, Drabeskos and Athens, nor is it a public register of transactions of the entire community, like the list from Tenos. The integration of the new fragment to the plaque leaves little doubt that, contrary to what I previously thought, ${ }^{38}$ it is a list of purchases by a single private individual, which can have been set up only by that person himself. In other words this list of deeds of sale performed the same function as the single deeds of sale that we know from other parts of Macedonia and specifically from Amphipolis and Tyrissa (?). In all these cases, the stelae, blocks or plaques inscribed with deeds of sale were private documents set up on the very properties, the ownership of which they were meant to establish. These properties might be buildings, but also land, such as vineyards in the territory of Amphipolis. ${ }^{39}$ or of Tyrissa (?). ${ }^{40}$ What singles out the document from Mieza is that it is not an irregular block carelessly cut and destined to be fixed on the ground or built in a construction, like the other two rural examples, but a very carefully cut and inscribed plaque which was probably meant to be fixed as a revetment on a wall. It would be very interesting to know whether this wall belonged to a country house or some rural sanctuary, but the information

36. Cf. IG II/III 1579-89.

37. IG XII 5, 872. Cf. R. Etienne, Ténos II. Ténos et les Cyclades du milieu du IVe siècle av.J.C. au milieu du IIIe siècle av. J.C. (Athens-Paris 1990) 51-84.

38. Cf. Hatzopoulos, "Quaestiones" 52.

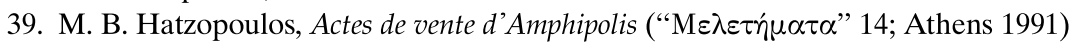
33-38, no VII; id., Institutions II 101-102, no 87.

40. See note 33 , above. 
available does not allow us to go any farther. In any case this building, whatever its nature, was most probably situated on the property of Zopyros son of Gorgias.

\section{2) The territory of Mieza, its neighbouring cities and the constitution of extensive properties}

The ten deeds inscribed on the plaque found in the Tomb of the Judgment bear witness to massive purchase of land by Zopyros son of Gorgias. Ten properties were apparently bought in three consecutive years, four of which in the very same month, for certainly more than 25.506 drachmae, which represent the value of only three of them. We also learn that Zopyros possessed or had already in the past acquired three other properties in the same area. Unfortunately, the size of seven out of the ten properties registered on the plaque is missing. The average size which can be reckoned from the three better preserved deeds would be in the order of 10 hectares. Multiplied by ten, it would give a sum of 100 hectares, which is a little less than the sum of the properties granted by Lysimachos to Harpalos. At a mean price of $67(70+64: 2)$ drachmae per plethron the value of the ten properties would add to more than 80.000 drachmae, a sum comparable to my evaluation of the properties donated to Harpalos (75.000). ${ }^{41}$ These figures are obviously arbitrary, but they might give a useful intimation about the importance of Zopyros' real estate dealings.

Another equally significant aspect of Zopyros' real estate activities is his manifest endeavour to merge the land he acquired into a continuous estate. Out of the ten recorded transactions the first three concern the area around Droiestai, the next four lands by the river (?) Sisias and, among the last three, two at least the place called Gaimeion. Furthermore, it is noteworthy that Zopyros had already acquired two pieces of land at the first location and already possessed one in the second. We might have known more similar cases had the second "page" of the document been complete.

Out of the three place names mentioned above we can securely locate the first one, which is twice connected with Nea Polis. It is remarkable that in the three relevant deeds figure prominently citizens of Skydra and Marinia, located respectively at the modern villages of Arseni and Marina to the north-east and north-west of Mieza. Until very recently no city of the name of Neapolis was known at this part of Macedonia. However, a third century B.C. decree of Kyrrhos discovered in 1971

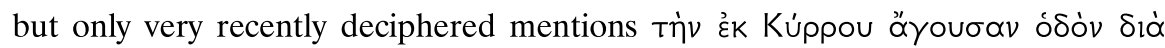

41. Hatzopoulos, Donation 51. 


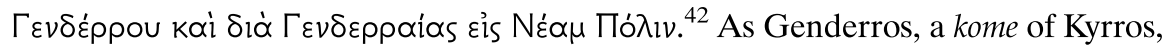
was situated in the area of Mandalon-Anydron, ${ }^{43}$ it is very probable that the route referred to in the decree is the one which, after following an east-west course from Aravissos to Mandalon, turned at a right angle due south joining at Mavrovouni the main road leading to Beroia. The naming of the road by reference to Nea Polis signifies that Nea Polis was the first community possessing the status of a city which it met on its course. The single site with ancient remains identified on that road between Mandalon/ancient Genderros and Leukadia/ancient Mieza is the village of Episkopi, where the church of the Taxiarchai is built from ancient spolia. ${ }^{44}$ Now Episkopi lies north of Leukadia (ancient Mieza), south of Marina (ancient Marinia) and west of Arseni (ancient Skydra). We can conclude that the first three real estate purchases recorded on the plaque were concentrated in the exteme north of the territory of Mieza, in the border area with Nea Polis. Droiestai or Droestai, meaning "those of the oak tree", ${ }^{45}$ was probably a small community in this area. The

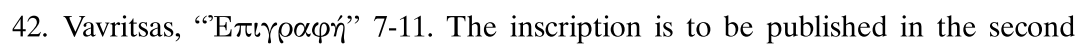

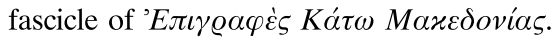

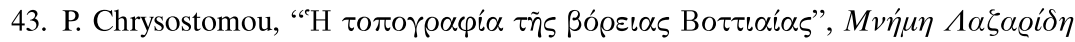

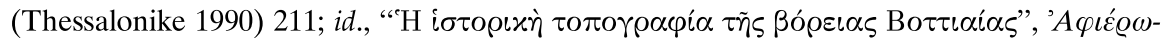

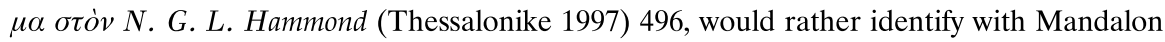
the place name Mandarai, attested in Stephanos Byzantios, s.v. However, Fanoula Papazoglou, Les villes de Macédoine à l'époque romaine (Athens-Paris 1988) 154, rightly points out that

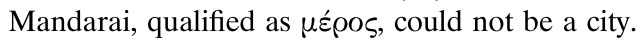

44. A. Struck, Makedonische Fahrten II. Die makedonischen Niederlande (Sarajevo 1908) 56. The ancient site at Roundina on the territory of the community of Episkopi has been declared an archaelogically protected area. The early Hellenistic temple recently discovered in the south-western outskirts of modern Skydra (formerly Vertekop) remains until now isolated, and cannot be connected to any known ancient community. Cf. Anastasia Chryso-

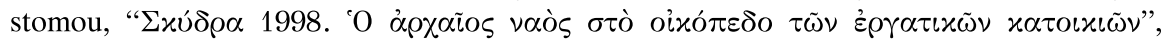

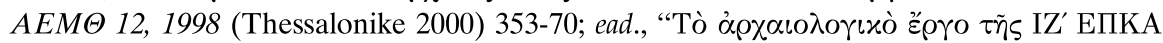

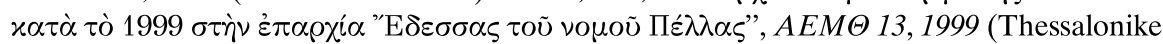
2001) 508-509.

45. It is probable that the Macedonians, even when using the Attic koine, continued to pronounce $/ u$ / the sound that the mouth of the Athenians had long since become an $/ y /$. Since by the third century B.C. the ancient diphthong /oi/had been reduced to $/ y /$, o $\mathrm{had}$ become an alternative spelling for that sound in the Attic koine and, respectively, for the sound $/ u / \mathrm{n}$ its Macedonian variety. On the other hand the very closed pronunciation of $/ o /$ in Macedonia caused spelling confusions between omicron and upsilon retaining the value of $/ u$ /

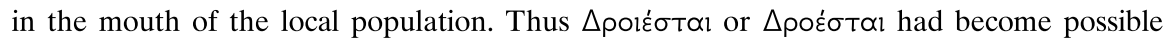

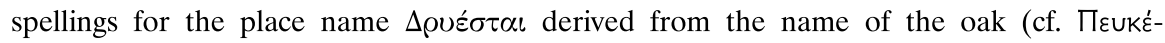
$\sigma \tau \alpha l=$ "those of the pine tree"). 
presence of the same person, Olympichos son of Sakolas, who figures as a witness in two deeds (nos 2 and 3) dealing with the purchase of land in the Droiestai area and as a guarantor in at least two of the transactions regarding properties by the Sisias (deeds no 4 and 6) is a strong indication that this river(?) too was located in the same area. Olympichos is also present at least in one of the two deeds (no 10) dealing with properties at Gaimeion, while Paramonos son of Kephis[---], who witnesses a deed concerning land by the Sisias, is also a guarantor of one of the two deeds regarding Gaimeion. Both facts suggest that Gaimeion too lay in the same border area at the extreme north of the territory of Mieza, from Marinia to the west to Skydra to the east. Finally, it is probable that the person from whom Zopyros bought landed property by the remaining deed (no 9) was a citizen of Nea Polis, again an indication of the northern location of the real estate. In fact a prosopographical study of the persons mentioned in these ten deeds shows clearly that we are dealing with a small number of persons from a closely knit community acting in various capacities. Actually, out of 29 persons recorded ten at least appear in more than one capacity.

If my reasoning up to this point is valid, the mutilated plaque from the Tomb of the Judgment reveals the consistent efforts of a rich citizen of Mieza to constitute a vast estate in the northern border of the civic territory. This raises the question how an estate, such as the one that Zopyros endeavoured to constitute, was exploited.

Fanoula Papazoglou in a study devoted to the population of the Roman colonies in Macedonia suggested that the incolae or $\pi$ ó $\rho \circ \iota x \mathrm{~s}$ attested in the epigraphic documents were the descendants partly of the former citizens and partly of the inhabitants of the chora attached to the cities converted into Roman colonies, who before the foundation of the latter occupied an inferior status and were free but deprived of political rights. ${ }^{46}$ Two years later, commenting on this suggestion, I wrote that in the absence of decisive evidence I would be sceptical about the existence of a free but disenfranchised population in the Macedonian cities before the Roman colonisation, for the epigraphic documents of the Hellenistic period revealed no trace of such a population in the cities, as opposed to the royal lands, where it was effectively attested. ${ }^{47}$ In her later monograph on the subject of laoi and paroikoi the same Yugoslav scholar noted that such population groups were not and

46. Fanoula Papazoglou, "La population des colonies romaines de Macédoine", $\check{Z} A$ 40 (1990) 111-24.

47. BullEpigr 1992, 297. 
could not be attested in the possessions of the Antigonid kings. ${ }^{48}$ In a note she mentioned the assertions to the contrary by earlier authors, ${ }^{49}$ but insisted on the absence of relevant evidence.

In fact, as it has already been noted by F. W. Walbank, ${ }^{50}$ indirect evidence is not altogether lacking. Livy, after Polybius narrates how in 182 B.C. Philip V established Thracians "and other barbarians" in Emathia. ${ }^{51}$ Their status is not clearly defined, but it is doubtful that, as Livy (Polybius) would have us believe in his dramatic narrative, they replaced as full citizens the former Macedonian population. Thracian incolae, along with Paeonians and Agrianes, reappear nine years later at the army review of Kyrrhos, ${ }^{52}$ but the context suggests that they originated from the north-eastern frontier of the kingdom. Gauls too are mentioned in the same narrative, but without any indication of their origin. ${ }^{53}$ Finally, in his description of the Roman settlement after the Third Macedonian War, Livy (Polybius) states that the Third Meris, that is the Old Kingdom, contained very many Gaul and Illyrian incolae, qualified as "diligent farmers". 54

In fact, we know that the practice of the transfer of populations goes back at least to Philip II, ${ }^{55}$ and that it was pursued by his successors. It is also known that Cassander established Autariatae in Orbelia, ${ }^{56}$ and it has been suggested that the Macedonian kings, such as Antigonos Gonatas and his successors, who made extensive use of barbarian mercenaries, attracted them into their service with the promise of settling them on the land once they were discharged. ${ }^{57}$ This suggestion seems to be confirmed by onomastic evidence. Argyro Tataki has posited that the Illyrian, Thracian and Celtic personal names encountered in Edessa in the Roman

48. Fanoula Papazoglou, Laoi et paroikoi. Recherches sur la structure de la société hellénistique (Belgrade 1997) 2.

49. J. R. Ellis, Philip II and Macedonian Imperialism (London 1986) 27; K. J. Beloch, Griechische Geschichte, vol. III, I (Berlin-Leipzig 1922²) 296.

50. F. W. Walbank, Philip V of Macedon Cambridge 1940) 243-44.

51. Livy 40.3-4.

52. This is the real place name lying behind the corrupt manuscript reading. See Hatzopoulos, Institutions I 114, n. 5.

53. Livy 42.51.5-6.

54. Livy 45.30 .5 .

55. Just. 8.5.7 and 8.6.1.

56. Diod. 20.19.1; Just. 15.2.1; Oros. 3.23.36.

57. W. W. Tarn, Antigonos Gonatas (Oxford 1913); G. T. Griffith, The Mercenaries of the Hellenistic World (Cambridge 1935) 73; 77-78. M. Launey, Recherches sur les armées hellénistiques (Paris 1949) 416. 
period must be connected with the settlement of barbarians by Antigonid kings in that area. ${ }^{58}$ It could be argued that the presence of these individuals in the Central Macedonian Plain many centuries later may have obeyed to other motives. Prudence dictates to take into consideration Hellenistic evidence only. In that period, at least three Illyrian names are epigraphically attested at Pella, ${ }^{59}$ at least three Celtic names appear in dedications to the sanctuary of Athena at Kyrrhos, ${ }^{60}$ three bearers of Thracian and three of Illyrian names are known from Beroia, and a single bearer of an Illyrian name in Mieza. ${ }^{61}$ However, explicit confirmation of the presence of laoi in Antigonid Macedonia came with the - unfortunately incomplete

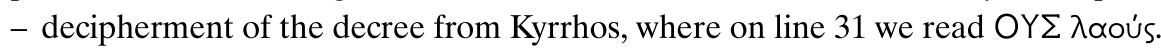

On the basis of the above it is legitimate to conclude that dependent populations did exist in Hellenistic Macedonia, and, moreover that their presence was not confined to the New Lands, but that these were also active in the Old Kingdom. The answer to the question whether they assured the cultivation of royal land only or were also active on privately owned civic territory, such as the estate of Zopyros son of Gorgias, still remains beyond our grasp.

\section{A LIST OF SALES FROM MIEZA}

PAGE A

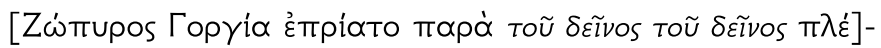

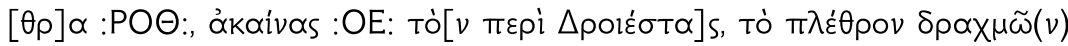

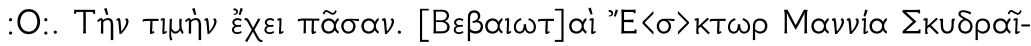

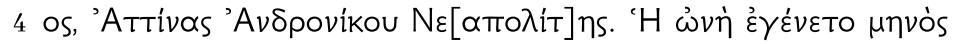

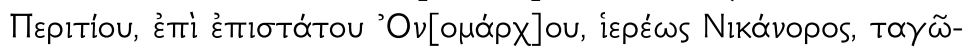

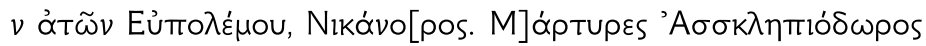

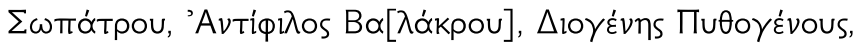

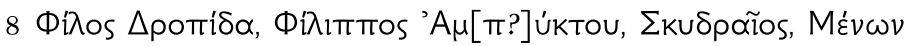

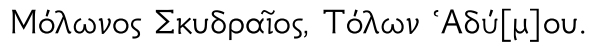

Z

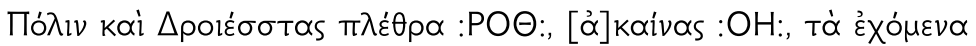

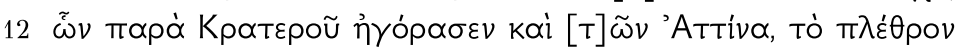

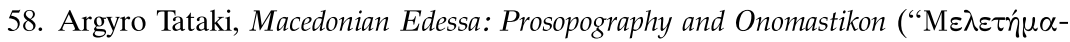
$\tau \alpha " 18$; Athens 1944) 104-105.

59. SEG XXIV 551; XXXVIII 653.

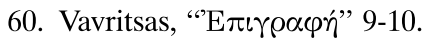

61. Cf. Tataki, Beroea 350 and 359; A. Struck, "Inschriften aus Makedonien", AM 27 (1902) 314, no 28 . 


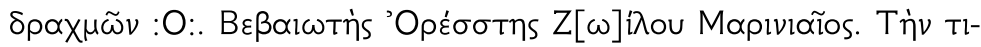

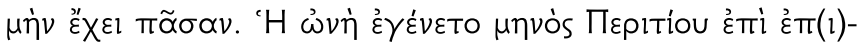

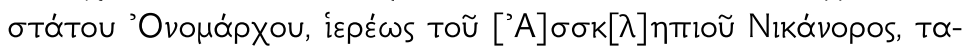

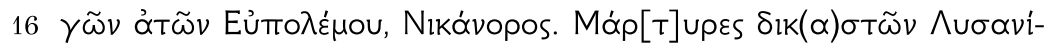

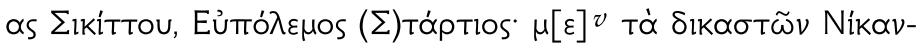

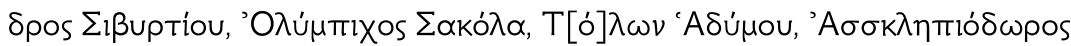

$\sum \omega \pi \alpha \dot{t}$ точ.

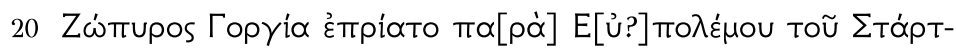

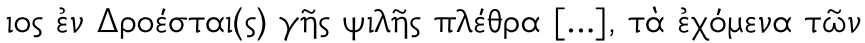

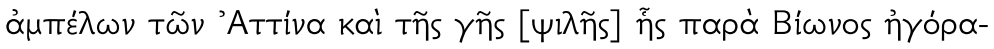

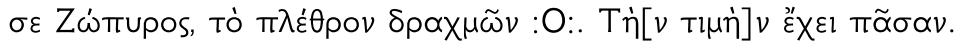

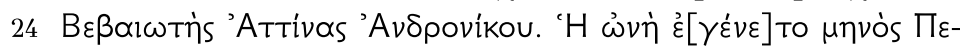

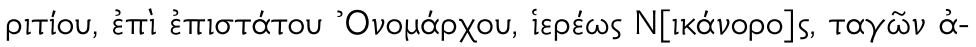

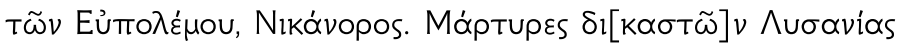

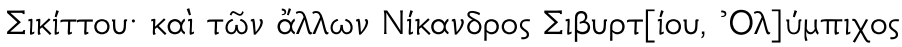

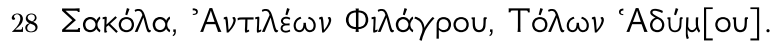

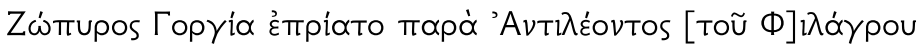

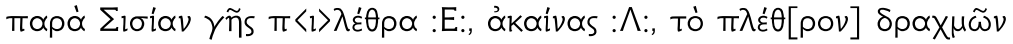

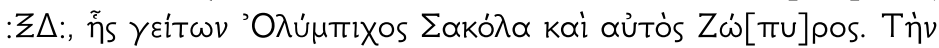

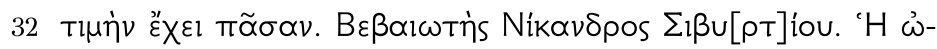

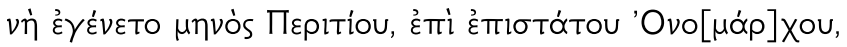

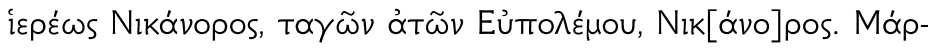

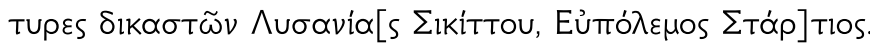

\section{PAGE B}

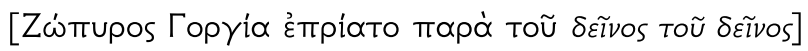

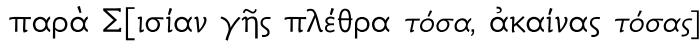

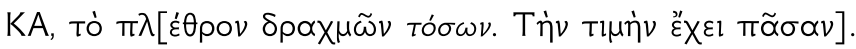

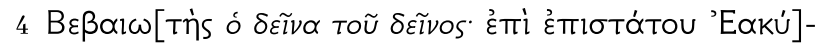

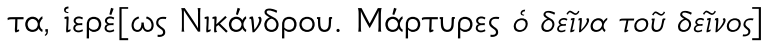

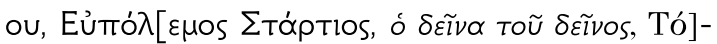

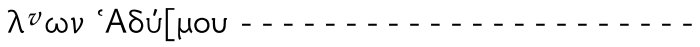

8 Z

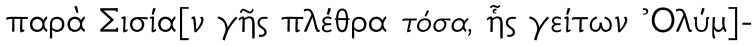

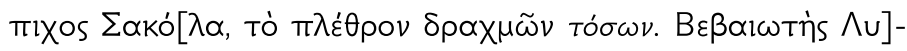

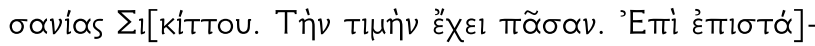

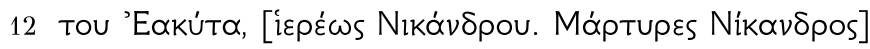




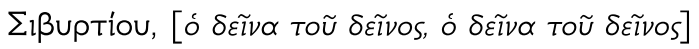

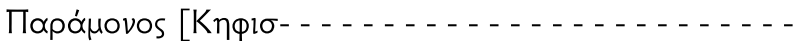

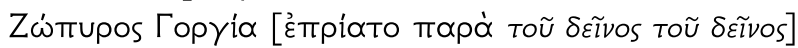

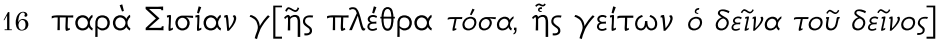

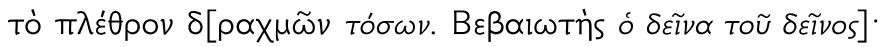

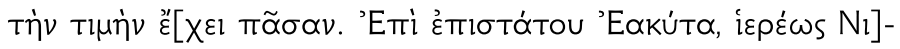

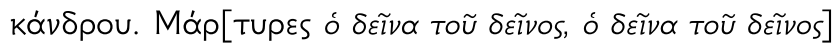

20 Nikón $v \omega \rho$ 'A $\lambda[--$

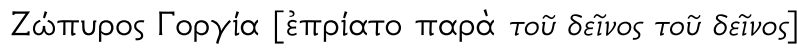

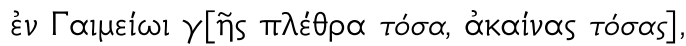

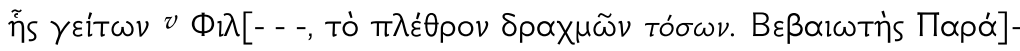

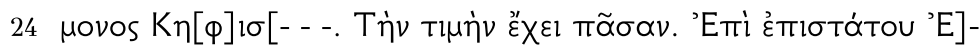

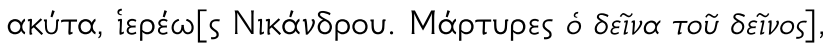

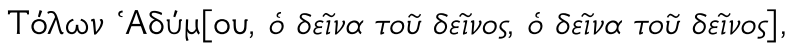

Фіג

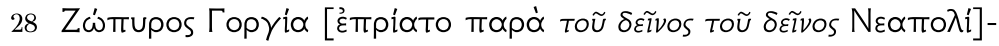

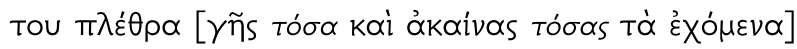

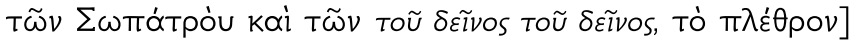

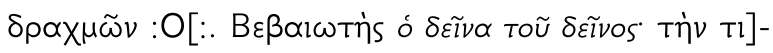

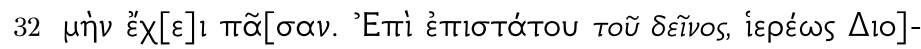

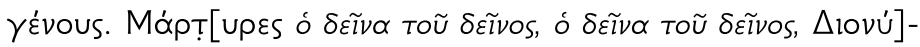

бlos $\sum \omega \pi \alpha \dot{t} \mathrm{\rho}[\mathrm{ou}]$.

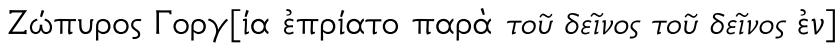

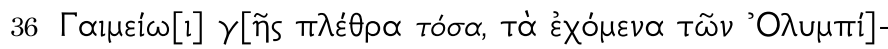

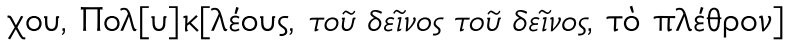

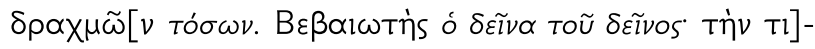

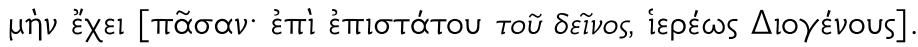

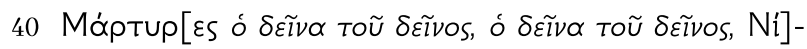

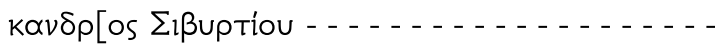

Page A. For reasons previously explained I have interpreted the sequence TA $\Gamma \mathrm{NAT} \Omega \mathrm{N}$ as

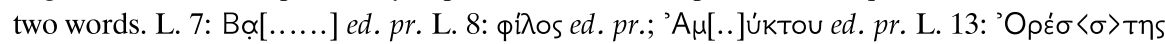
$e d$. pr., but without reason, since the spelling reflects a phonetic phenomenon. L. 17: Tóptios ed. pr., but there is no doubt that the cutter has inadvertantly omitted to engrave a second sigma after the final sigma of the previous word; the beginning of this name figures at the end

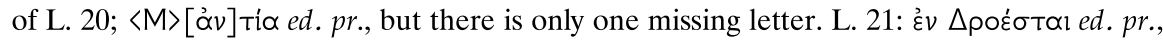
but the final sigma has been obviously omitted by mistake, for the place name in all other

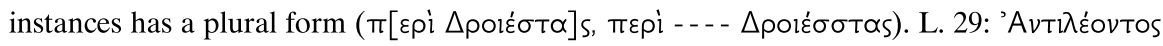


$[\Phi]$ !̣ $\lambda$ ó $\gamma$ pou, ed. pr., but the definitive article is expected and there is the necessary space in the lacuna.

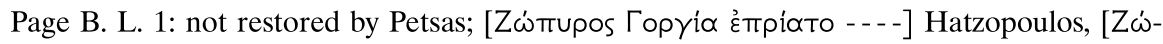

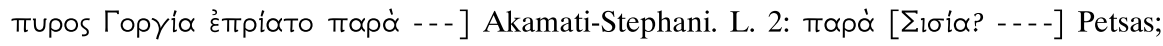

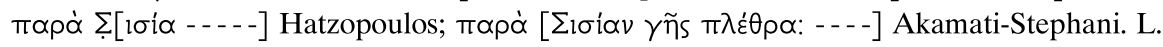

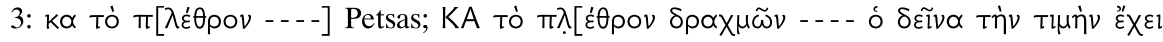

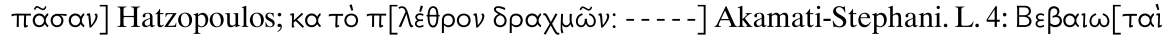

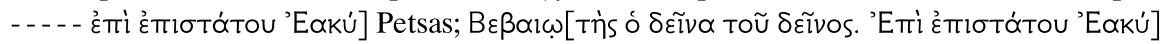

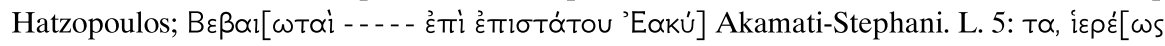

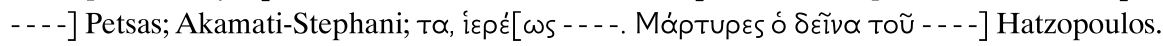

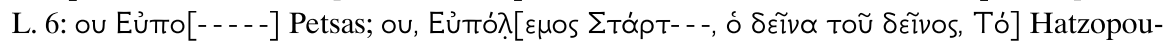

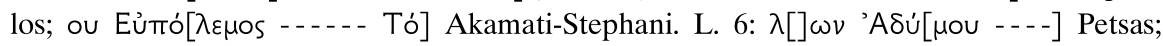

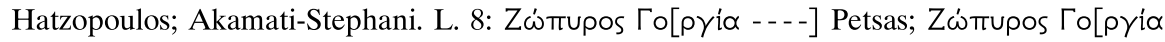

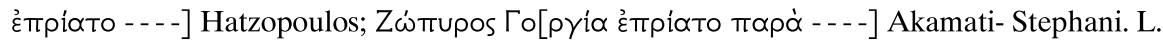

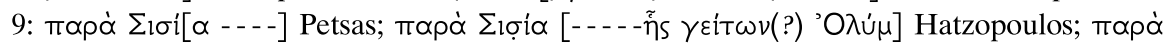

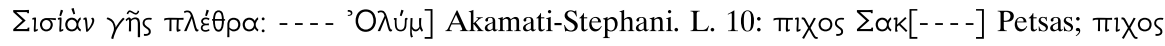

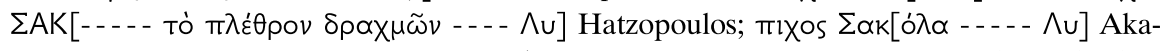

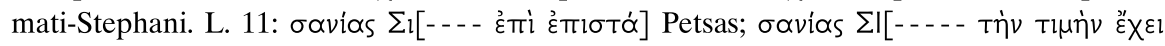

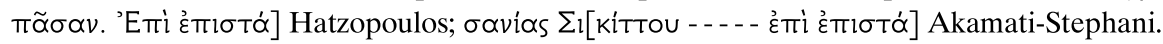

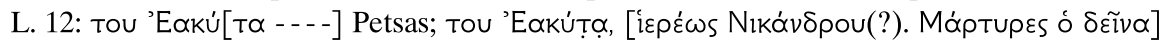

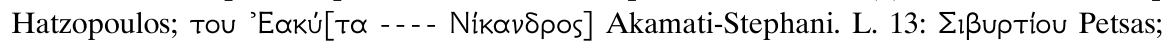

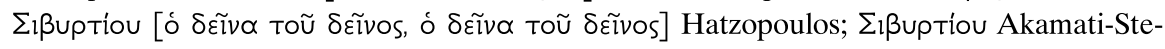

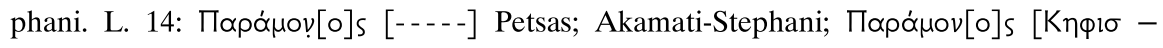

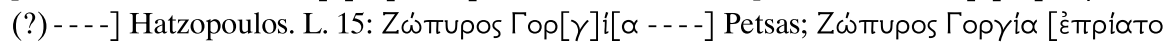

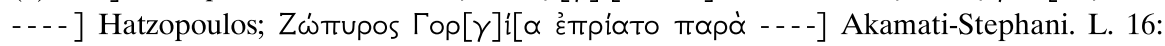

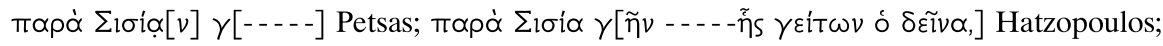

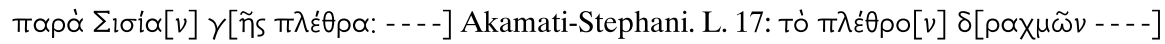

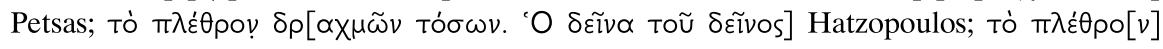

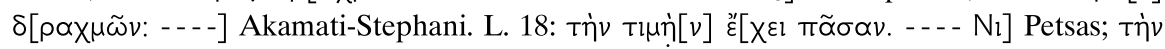

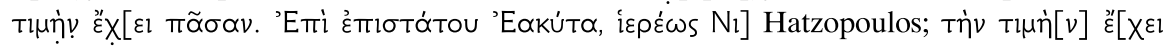

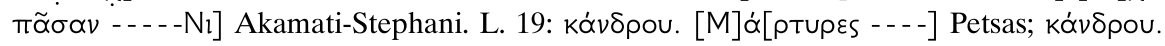

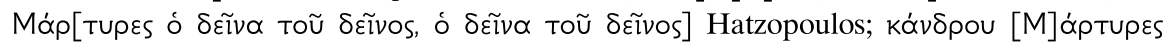

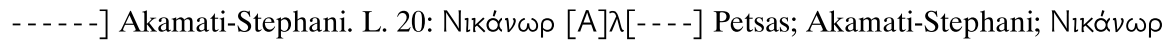

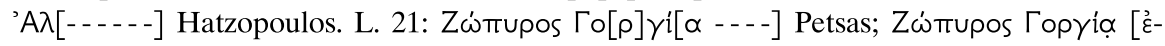

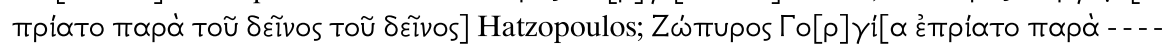

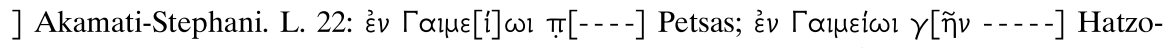

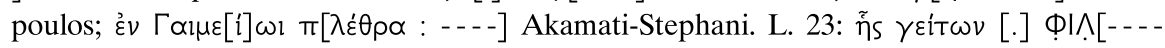

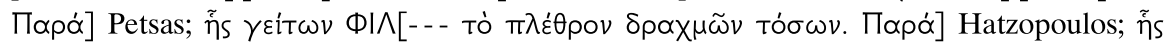

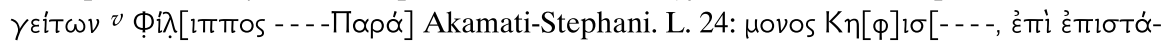

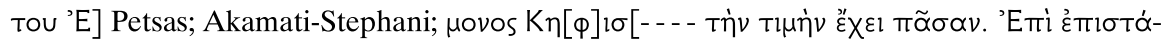

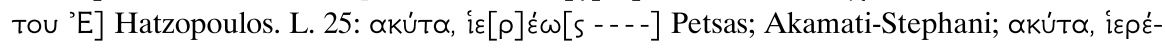




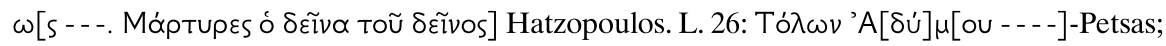

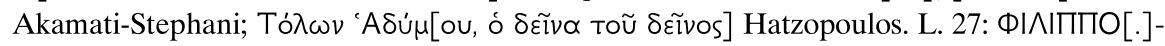

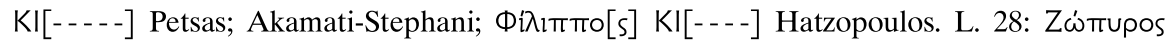

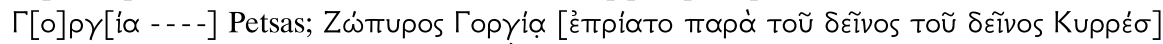

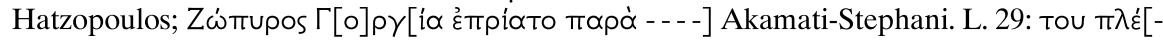

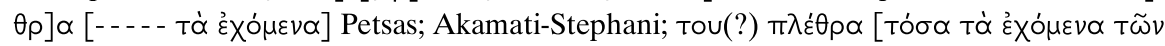

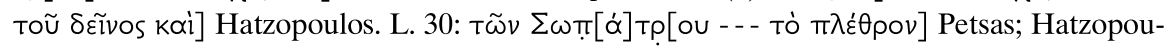

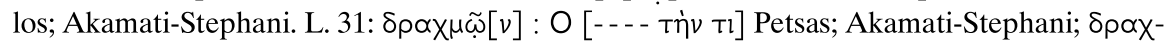

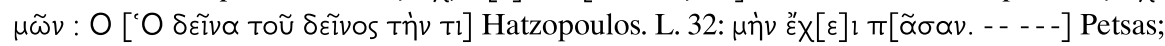

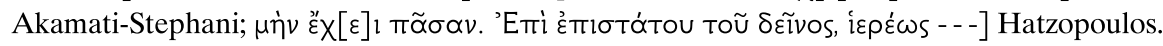

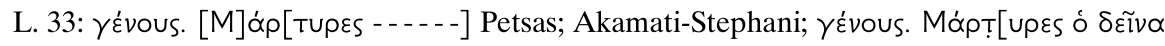

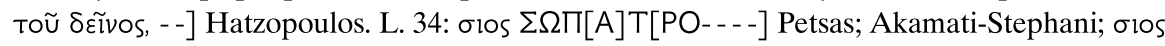

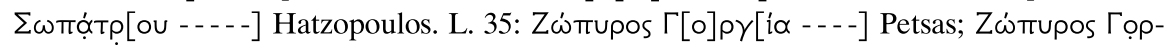

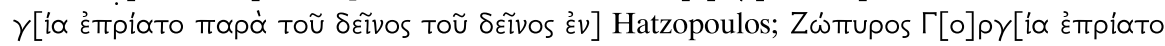

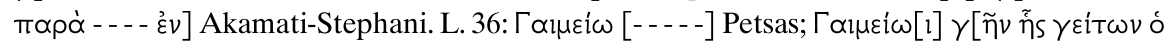

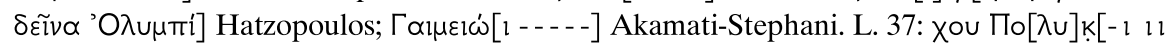

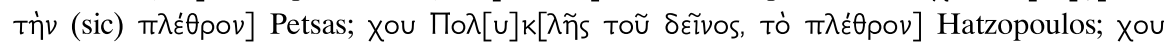

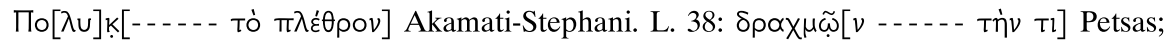

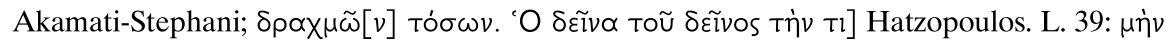

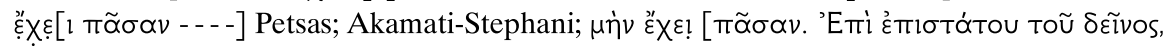

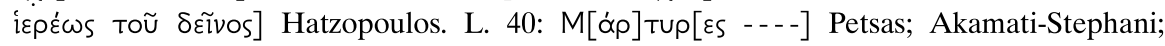

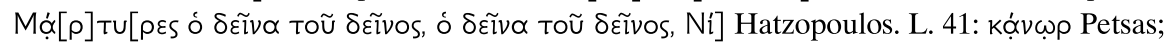

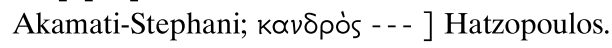

\begin{tabular}{|c|c|}
\hline \multicolumn{2}{|c|}{ Abbreviations } \\
\hline Bouthrotos & $\begin{array}{l}\text { P. Cabanes et al., Inscriptions de Bouthrotos } \\
\text { (Athens-Paris 2007). }\end{array}$ \\
\hline Chantraine, Dictionnaire & $\begin{array}{l}\text { P. Chantraine et al., Dictionnaire étymologique de la } \\
\text { langue grecque (Paris 1968-1980). }\end{array}$ \\
\hline Chrysostomou, " $\Delta \iota x \alpha \sigma \tau \alpha \iota "$ & 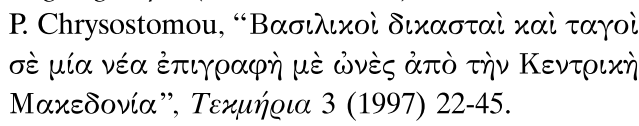 \\
\hline$E K M \mathrm{I}$ & 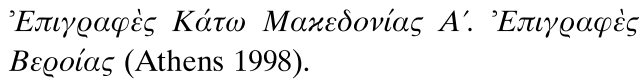 \\
\hline Faraguna, "Archivi" & $\begin{array}{l}\text { M. Faraguna, "A proposito degli archivi nel mondo } \\
\text { greco: terra e registrazioni fondiarie", Chiron } 30 \\
(2000) 65-115 \text {. }\end{array}$ \\
\hline Giouni, " $\Omega \nu \alpha \imath "$ & 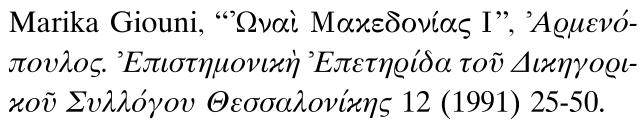 \\
\hline
\end{tabular}


Hatzopoulos, Donation

Hatzopoulos, "X $\omega \dot{\rho} \alpha "$

Hatzopoulos, Institutions

Hatzopoulos, "Quaestiones”

Hatzopoulos-Loukopoulou, Recherches

Leukopétra

$L G P N$

Lilimbaki - Stephani, "' $\Omega \nu \alpha i ”$

Petsas, "' $\Omega \nu \alpha i "$

Tataki, Beroea

Vavritsas, "'E $\pi \imath \gamma \rho \alpha \varphi \eta ' ”$
M. B. Hatzopoulos, Une donation du roi Lysimaque

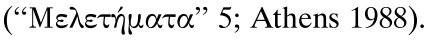

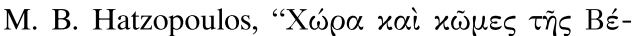

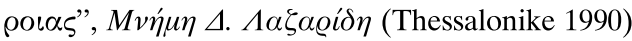
57-68.

M. B. Hatzopoulos, Macedonian Institutions under

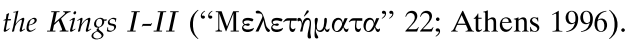

M. B. Hatzopoulos, "Quaestiones macedonicae: lois, décrets et épistates dans les cités macédo-

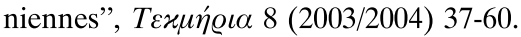

M. B. Hatzopoulos-Louisa D. Loukopoulou, Recherches sur les marches orientales des Téménides I-II ("M $\varepsilon \lambda \varepsilon \tau \dot{\eta} \mu \alpha \tau \alpha " 11$; Athens 1992-1996).

Ph. Petsas, M. B. Hatzopoulos, Lucrèce Gounaropoulou, P. Paschidis, Inscriptions du sanctuaire de la Mère des Dieux Autochtone à Leukopétra (Macédoine) ("M $\varepsilon \lambda \varepsilon \tau \dot{\eta} \mu \alpha \tau \alpha " 28 ;$ Athens 2000).

Lexicon of Greek Personal Names I-IV (Oxford 19872005).

Maria Lilimbaki-Akamati $\mathcal{E}$ Liana Stephani, "' $\Omega$ -

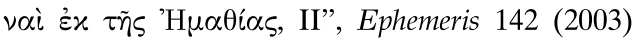
[2005] 155-96.

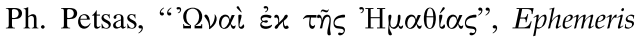
1961, 1-57.

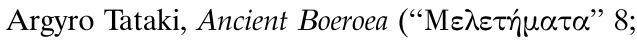
Athens 1988).

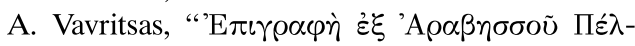
$\lambda \eta \varsigma^{\prime}$, Ancient Macedonia II (Thessalonike 1977) 711. 